\title{
Lactate dehydrogenase of Mugil sp. (Mugilidae, Perciformes). Lack of electrokinetic, thermostability and kinetic differences among individuals with different number of scales
}

\author{
Marcelo dos Santos, Maria Luiza B. Schwantes and Arno Rudi Schwantes
}

\begin{abstract}
The scale number in lateral sets (SNS) of Mugil sp. (Mugilidae, Perciformes) collected in the lagoon-estuarine region of Cananéia, State of São Paulo ranges from 33 to 39. Electrokinetic, kinetic and thermostability properties of lactate dehydrogenase (LDH) were tested to determine if individuals with different SNS correspond to different species or populations of mullet. As in many other teleosts, $L D H$ - $A *$, $L D H-B^{*}$, and $L D H-C^{*}$ loci were detected. Through a two-fold serial dilution method applied to 10 different tissues of $M u g i l$ sp., a bidirectionally divergent expression of these loci was suggested. No association among LDH electrophoretic pattern, thermal inactivation, kinetic responses and different SNS was observed. The apparent $K_{\mathrm{m}}$ (pyr) values obtained here were similar to $K_{\mathrm{m}}$ values obtained by other authors for muscle and heart LDH or their purified isoforms. The effect of $\mathrm{NaCl}$ on $K_{\mathrm{m}}$ and $V_{\max }$ values of Mugil sp. (35 and $39 \mathrm{SNS}$ individuals) indicates that this salt behaves as a competitive inhibitor, since it decreases enzyme-substrate affinity. Thus, electrokinetic and thermostability behavior, $K_{\mathrm{m}}$ and $V_{\max }$ values and the effect of $\mathrm{NaCl}$ do not permit us to consider these mullets, with SNS ranging from 33 to 39 , as belonging to different populations or species.
\end{abstract}

\section{INTRODUCTION}

Lactate dehydrogenase (LDH; EC 1.1.1.27) isoforms in fish, coded at two or three loci, $L D H-A^{*}, L D H-B^{*}$ and $L D H-C^{*}$, have been the subject of many studies (Markert and Faulhaber, 1965; Panepucci et al., 1984, 1987; Coppes et al., 1987; Almeida-Val et al., 1990, 1991; Fenerich-Verani et al., 1990; Ferreira et al., 1991).

Mugilidae fish inhabit various geographical regions, occurring in tropical and subtropical waters throughout the world. In Brazil, mullets occur along the entire coast. They are commonly called tainhas and paratis in southern and southeastern regions, and tainhas and curimãs in northern and northeastern regions (Braga, 1978). The Mugil genus consists of seven species two of which are tainhas - $M$. liza and M. platanus - and five are paratis - M. curema, $M$. trichodon, M. incilis, M. gairmardianus and M. curvidens (Menezes, 1983). According to Menezes and Figueredo (1985), two of these species, with different scale numbers in lateral sets (SNS), occur in the southern and southeastern regions having the State of Rio de Janeiro separating both. While $M$. liza has an SNS range of 29-36, M. platanus has a SNS range of 35-41. Thus, the present study describes the electrokinetic, kinetic and thermostability properties of LDH from Mugil sp. (Mugilidae, Perciformes), with SNS ranging from 33 to 39, collected in the lagoon-estuarine region of Cananéia, State of São Paulo, Brazil, for the purpose of determining if different species or populations inhabit this area. We also describe the effect of $\mathrm{NaCl}$ concentrations on 35 and 39 mullet enzyme-substrate affinity, since they inhabit unstable environments, and a high tolerance to changes in salinity could be expected.

\section{MATERIAL AND METHODS}

All Mugil sp. specimens were collected in the lagoonestuarine region of Cananéia ( $25^{\circ} 01^{\prime} 00^{\prime \prime} S$ ), SP, Brazil. The 80 individuals studied here have SNS ranging from 33 to 39 . The presence of ripe or enlarged gonads indicated that all individuals were sexually mature. For electrophoretic analyses approximately equal amounts of the following tissues - skeletal muscle, heart, liver, gonad, gill, eye, stomach, kidney, spleen and brain - from each individual were dissected immediately after capture and kept at $-20^{\circ} \mathrm{C}$. A small piece of each tissue was homogenized in $50 \mathrm{mM}$ phosphate buffer, $\mathrm{pH} 8.5$, using a Potter-Elvejhem tissue grinder, and then centrifuged at $27,000 \mathrm{~g}$ for $30 \mathrm{~min}$ at $4^{\circ} \mathrm{C}$. The resulting crude extracts were immediately subjected to electrophoresis.

Electrophoresis was carried out in horizontal gels containing $13 \%(\mathrm{w} / \mathrm{v})$ corn starch prepared according to Val et al. (1980) using Boyer et al. (1963) buffer system. Electrophoresis was carried out at $4{ }^{\circ} \mathrm{C}$ with a voltage gradient of about $5 \mathrm{~V} / \mathrm{cm}$ for $15 \mathrm{~h}$. Contributions of duplicate genes to the isozyme activities in each tissue were quanti- 
fied by Klebe's method (1975). After electrophoresis, the starch gels were sliced lengthwise and the lower halves incubated in the dark in an LDH staining solution described by Shaklee et al. (1973) modified with $1.5 \%$ agar. Gel preparations were carefully controlled in order to provide virtually identical electrophoretic conditions. Nomenclature of LDH gene loci was according to Shaklee et al. (1989).

Isolation of mullet LDH homotetramers was carried out using two different procedures. The first procedure used an electrophoretic technique according to De Luca et al. (1983). In the second procedure, only the A-isoform was isolated from skeletal muscle extracts, using an FPLC system. This tissue was homogenized and centrifuged at 27,000 $g$ for $30 \mathrm{~min}$ at $4^{\circ} \mathrm{C}$, and the supernatant was immediately subjected to a Mono-Q HR 5/5 anion exchange column (Pharmacia). Chromatographic analyses were performed using a $20 \mathrm{mM}$ Tris chloride buffer, $\mathrm{pH} 7.5$, in a salt linear gradient of $0-0.4 \mathrm{M} \mathrm{NaCl}$ for $20 \mathrm{~min}$ and $0.4-1 \mathrm{M} \mathrm{NaCl}$ for $10 \mathrm{~min}$, with a flow rate of $60 \mathrm{ml}$ per h.

The effect of temperature on mullet LDH was determined by subjecting $1.0 \mathrm{ml}$ of each skeletal muscle and heart extracts to $60^{\circ} \mathrm{C}$ for $10-60 \mathrm{~min}$. Their residual activities were examined at $25^{\circ} \mathrm{C}$ in the direction of pyruvate reduction by the change in absorbance at $340 \mathrm{~nm}$ in an HP8452A Diode Array Spectrophotometer using a temperature-controlled curvette holder. The assays were carried out in a $50 \mathrm{mM}$ imidazole chloride buffer, $\mathrm{pH} 7.5$, containing $0.33 \mathrm{mM}$ pyruvate and $0.13 \mathrm{mM}$ NADH. The effect of temperature on the activity of partially purified A and Bhomotetramers was measured by preincubation of $1.0 \mathrm{ml}$ of each to $45^{\circ}$ and $60^{\circ} \mathrm{C}$ for $1-10 \mathrm{~min}$ (measured at 1-min intervals) and 10-60 min (measured at 10-min intervals).

For estimating kinetic parameters, 16 substrate concentrations were assayed with two or three replicates (in at least three separate experiments). All were done at least in duplicate and initiated by adding $10 \mu \mathrm{l}$ of enzyme to $1.0 \mathrm{ml}$ of assay medium. The assay temperature of $25^{\circ} \mathrm{C}$ was controlled using a circulating thermo-bath LAUDA. Apparent Michaelis-Menten constants $\left(K_{\mathrm{m}}\right)$ and maximum catalytic rate $\left(V_{\max }\right)$ were calculated by the Lineweaver Burk method, using double-reciprocal plots of velocity vs. substrate concentrations.

Statistical differences among LDH gene divergences, thermal stability, $K_{\mathrm{m}}$ and $V_{\text {max }}$ values detected in tissues of Mugil sp. were determined by the nonparametric MannWhitney test (Zar, 1974) with a probability level of 0.05 chosen as the limit of statistical significance.

\section{RESULTS}

As in most vertebrates analyzed, electrophoretic pattern of mullet LDH shows both $L D H-A^{*}$ and $L D H-B^{*}$ loci (Figure 1). Skeletal muscle was characterized by a predominance of less anodically migrating components, and heart by the predominance of higher anodic components. The most anodic band, detected only in eye extracts, probably corresponds to the isoform codified by a third locus, $\mathrm{LDH}$ $C^{*}$, which is present only in certain groups of fish, such as the Perciformes studied here. Electrophoretic patterns of liver, gonad, kidney, brain, spleen, stomach and gill extracts were similar to those of the heart. Mullet electrophoretic patterns did not show any difference related to their SNS. A comparison of the relative activities of LDH isoforms in 10 tissues from each of the seven SNS classes analyzed was made (Table I). Statistical analyses of these molar ratios differed significantly only when specimens with SNS of 33 and 39, and of 38 and 39, were compared. Skeletal muscle extracts showed a mean proportion of $1.64 \mathrm{~A}$ to $1 \mathrm{~B}$ subunits; heart extracts, $1 \mathrm{~A}: 1.51 \mathrm{~B}$, and eye extracts, where three homopolymers were detected, 1A:2.05 B, 1A:2.47

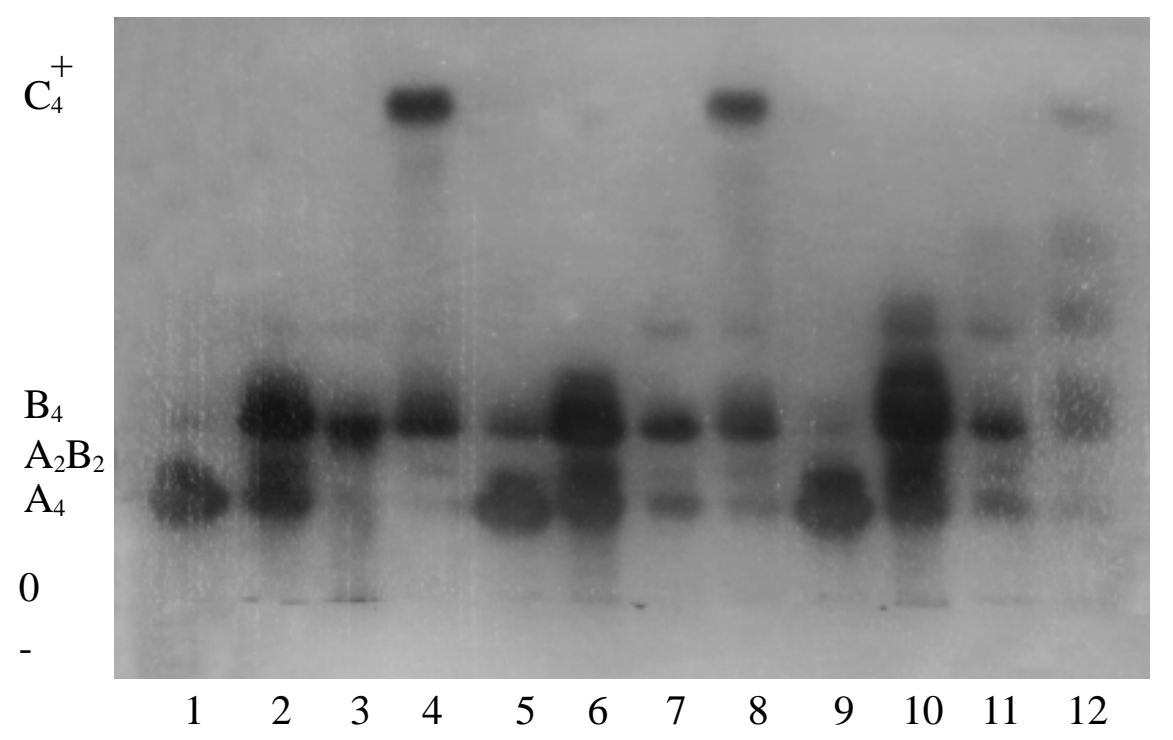

Figure 1 - LDH electrophoretic patterns observed in skeletal muscle $(1,5,9)$, heart $(2,6,10)$, gonad $(3$, $7,11)$, and eye $(4,8,12)$ extracts of Mugil sp. individuals with $33(1-4), 36(5-8)$ and $39(9-12)$ SNS. 
Table I - Expression of $L d h-A^{*}, L d h-B^{*}$ and $L d h-C^{*}$ in tissues from $M u g i l$ sp. with different scale number sets (SNS). The first value is the estimated ratio of subunits encoded by duplicated genes (proportion of homopolymer activity). The second value is the logarithm of such ratios. The minus (-) sign before the log indicates that the less anodally migrating isoform predominated.

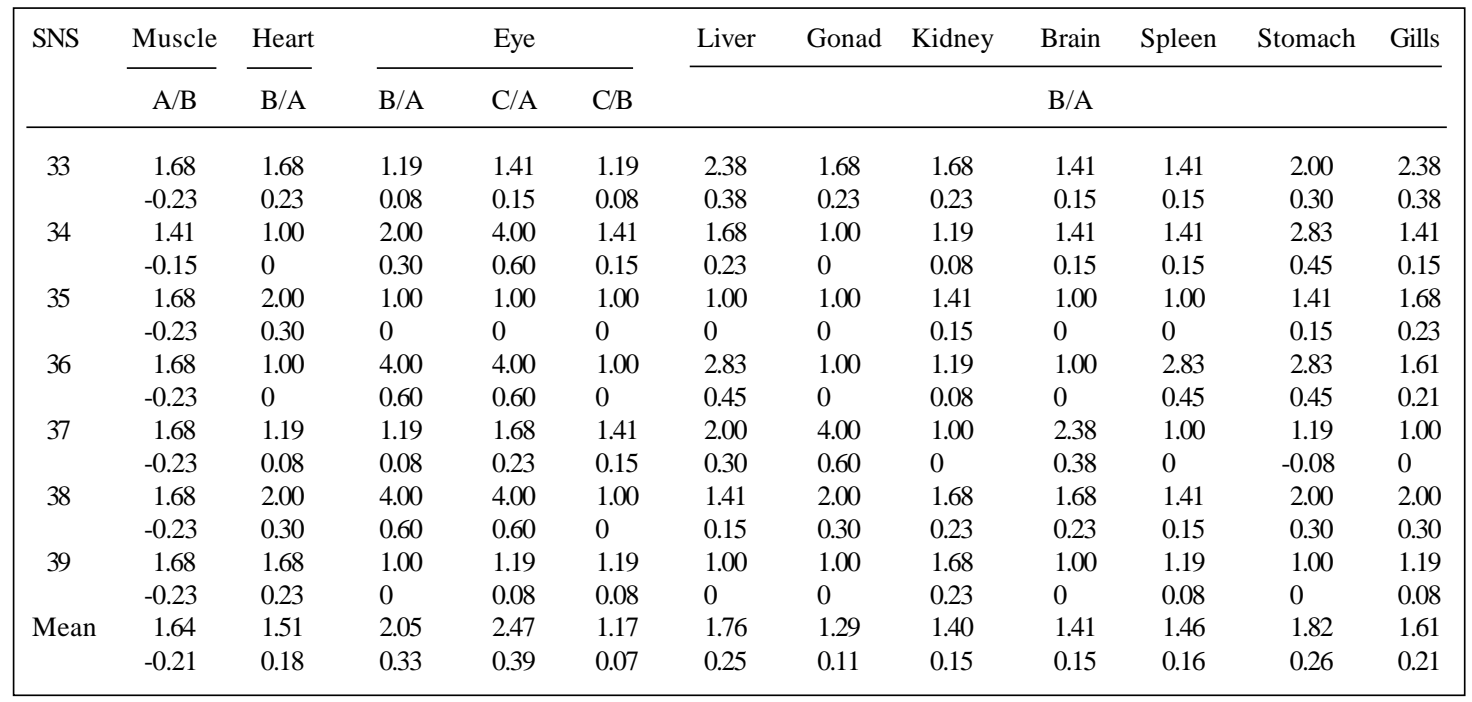

$\mathrm{C}$ and 1B:1.17 C. This different molar ratio of subunits characterizes a bidirectionally divergent pattern of gene expression. The mean log for the 10 tissues was $0.194 \pm$ 0.05 , which shows a divergent proportion of duplicate loci of 1.56. Among the analyzed tissues and SNS classes, eye extracts showed the lowest (1.17, between $L D H-B^{*}$ and $-C^{*}$ loci) and the highest divergences (2.47, between $L D H-A^{*}$ and $-C^{*}$ loci) of duplicate loci.

No significant difference was obtained when heat denaturation of LDH isoforms from specimens with different SNS (33, 36 and 39) was examined (Table II). When tissue extracts from these individuals were exposed to $60^{\circ} \mathrm{C}$ for various time periods in the absence of substrate or coenzyme, then assayed at $25^{\circ} \mathrm{C}$, the half-life in skeletal muscle extracts was about $6 \mathrm{~min}$, and in heart extracts about 8-9 min. However, when these experiments were conducted with A and B-isoforms separated through electrophoresis, their half-lives were 6 and $47 \mathrm{~min}$, respectively (Figure 2). Also, the A-isoform isolated by chromatography, incubated at $45^{\circ} \mathrm{C}$, showed a half-life of $4 \mathrm{~min}$ and at $60^{\circ} \mathrm{C}$ after 1 min no enzyme activity was observed. In order to compare the effect of substrate $(0.02-5$

Table II - Half-life of LDH activity after heating muscle and heart extracts from mullets with 33,36 and 39 scale number sets, at $60^{\circ} \mathrm{C}$ for various lengths of time.

\begin{tabular}{|cccc|}
\hline Tissues & \multicolumn{3}{c|}{ Scale number sets } \\
\cline { 2 - 4 } & 33 & 36 & 39 \\
\hline Skeletal muscle & $6 \mathrm{~min}$ & $6 \mathrm{~min}$ & $6 \mathrm{~min}$ \\
Heart muscle & $9 \mathrm{~min}$ & $9 \mathrm{~min}$ & $8 \mathrm{~min}$ \\
\hline
\end{tabular}

$\mathrm{mM})$ and $\mathrm{NaCl}(0.05,0.10$ and $0.50 \mathrm{mM})$ concentrations on LDH activity, we examined the responses of the apparent $K_{\mathrm{m}}$ and $V_{\max }$ of pyruvate on skeletal and heart muscles from pools of individuals with 35 and 39 SNS. $K_{\mathrm{m}}$ values obtained for skeletal muscle extracts $(0.43-0.93 \mathrm{mM})$ of both pools were higher than those obtained for their heart extracts $(0.10-0.18 \mathrm{mM})$, regardless of $\mathrm{NaCl}$ concentration (Table III). Increases in $\mathrm{NaCl}$ assay concentrations decreased enzyme-substrate affinity of muscle and heart extracts. Only heart $V_{\max }$ values were significantly different between both SNS classes.

\section{DISCUSSION}

Until recently it was generally assumed that the original vertebrate $\mathrm{LDH}$ subunit was the A type, that the duplication leading to the $\mathrm{B}$ subunit occurred prior to the divergence of lampreys and hagfish, and that the modern lampreys had lost expression of the B subunit gene. Since modern vertebrates, except for the lampreys, possess at least 2 genes which codify LDH polypeptides, the original $L D H-A^{*}$ gene must have suffered the duplication event very early. Later, these two genes similar to $A *$ diverged by mutation, giving rise to the two distinct genes detected here and in the majority of vertebrates: $L D H-A^{*}$ or muscle-type and $L D H-B^{*}$ or heart-type (Apella and Markert, 1961; Schwantes et al., 1969; Schwantes, 1973; Almeida-Val et al., 1990; Ferreira et al., 1991). However, in all SNS classes and Mugil tissues analyzed, only three of the five possible enzymatically active tetramers formed by the random association of the product of these two loci were detected, probably $\mathrm{A}_{4}, \mathrm{~A}_{2} \mathrm{~B}_{2}$, and $\mathrm{B}_{4}$. According to Goldberg and Wuntch (1967), one possible explanation of the three-band 


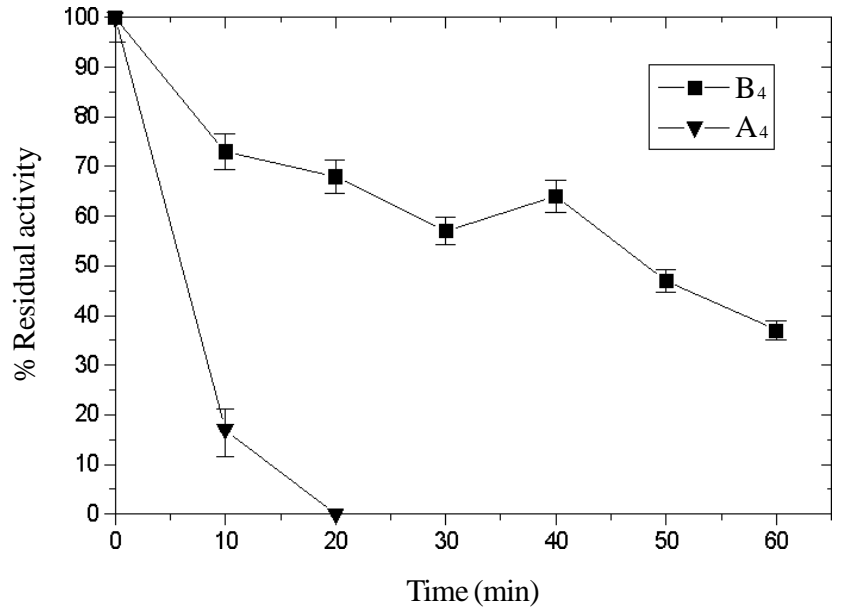

Figure 2 - Thermal inactivation of Mugil sp. lactate dehydrogenase A (triangles) and $\mathrm{B}$ (squares) isoforms at $60^{\circ} \mathrm{C}$ in $50 \mathrm{mM}$ imidazole chloride buffer, $\mathrm{pH} 7.5$. Aliquots were removed after heating the enzyme preparation for various time periods; remaining activity was measured at $25^{\circ} \mathrm{C}$. Initial pyruvate concentration $0.33 \mathrm{mM}, \mathrm{NADH} 0.13 \mathrm{mM}$. Error bars are $95 \%$ confidence intervals for each point determination.

Table III - Effect of $\mathrm{NaCl}(\mathrm{mM})$ concentration on the apparent $K_{\mathrm{m}}(\mathrm{mM})$

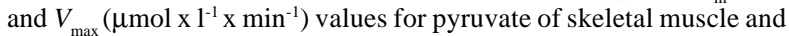
heart extracts from a pool of Mugil sp. individuals with 35 and 39 scale number sets (SNS).

\begin{tabular}{|c|c|c|c|c|c|c|c|c|}
\hline \multirow{3}{*}{$\begin{array}{l}\mathrm{NaCl} \\
(\mathrm{mM})\end{array}$} & \multicolumn{4}{|c|}{$\mathrm{SNS}=35$} & \multicolumn{4}{|c|}{$\mathrm{SNS}=39$} \\
\hline & \multicolumn{2}{|c|}{ Muscle } & \multicolumn{2}{|c|}{ Heart } & \multicolumn{2}{|c|}{ Muscle } & \multicolumn{2}{|c|}{ Heart } \\
\hline & $K_{\mathrm{m}}$ & $V_{\text {max }}$ & $K_{\mathrm{m}}$ & $V_{\max }$ & $K_{\mathrm{m}}$ & $V_{\max }$ & $K_{\mathrm{m}}$ & $V_{\text {max }}$ \\
\hline 0.00 & 0.46 & 0.40 & 0.13 & 0.11 & 0.43 & 0.68 & 0.10 & 0.09 \\
\hline 0.05 & 0.49 & 0.46 & 0.15 & 0.12 & 0.55 & 0.63 & 0.12 & 0.09 \\
\hline 0.10 & 0.60 & 0.48 & 0.19 & 0.12 & 0.74 & 0.77 & 0.16 & 0.10 \\
\hline 0.50 & 0.93 & 0.65 & 0.18 & 0.12 & 0.77 & 0.82 & 0.18 & 0.11 \\
\hline
\end{tabular}

pattern detected here is the association of two subunits in homodimers, with subsequent association in homotetramers and symmetric heterotetramers. However, Shaklee and Whitt (1977) proposed that the absence of heteropolymers formed between subunits A and B could be due to a temporal and/or spatial isolation of the genetic expression, a restriction on the association of subunits, or the differential lability of the heteropolymers. This pattern of three LDH isozymes seems to be common in fish (Markert and Faulhaber, 1965; Whitt et al., 1975; Almeida-Val et al., 1990; Ferreira et al., 1991).

In addition to the isozymes codified at these 2 loci, two specific, one eye (Markert and Faulhaber, 1965; Panepucci et al., 1984) and one liver (Markert et al., 1975), reveal that the majority of teleosts possess three $\mathrm{LDH}$ genes, of which the third is usually designated $\mathrm{LDH}-\mathrm{C}^{*}$. Shaklee et al. (1973), through electrophoretic and immu- nological data, suggested that the highly anodic band expressed in many teleosts, restricted to the eye and brain, and the cathodic band restricted to the liver are codified by the same locus. This third locus has also been detected in Mugil sp., codifying an eye-specific highly electronegative enzyme. However, this locus did not show the same degree of tissue restriction observed in other advanced teleosts, also appearing in cardiac muscle and gonad extracts as heteropolymers, possibly formed by the association of subunits B and C. This could indicate that in these tissues, C subunits would be synthesized in the same cell, region, or even at the same time as the B ones.

If we consider that the smaller the divergence in the expression of duplicated loci, the greater the degree of homology among them and their gene regulators, our results, using Klebe's method of serial dilutions (1975), might suggest that Mugil sp. $L D H-C^{*}$ have emerged from a more recent duplication from $L D H-B^{*}$. Thus, the average ratio of the expression of subunit $C$ in relation to $B$ detected in eye extracts was 1.17:1.00, while the average ratio of $\mathrm{C}$ in relation to $\mathrm{A}$ was $2.47: 1.00$. However, recent studies indicate that the $\mathrm{C}$ subunit predates the gene duplications that gave rise to the A and B subunits (Li et al., 1983).

According to Fisher and Whitt (1978), the ability to develop a differing ratio among tissues in active duplicated genes is in part related to the degree of metabolic homeostasis of the tissues and the metabolic level of their cells. Functional specialization of an enzyme is measured by the extent to which it is expressed in a determined number of tissues, the least specialized being expressed in a greater number of tissues. Ferris and Whitt (1979) suggested that two processes may contribute to the divergence of duplicated gene expression: i) changes in the structural genes that would alter their catalytic efficiency and/or the ability of one of the subunits codified by them, and/or ii) the accumulation of mutational differences in the regulating genes. According to the classification of duplicated genes, $L D H-A^{*}$, $L D H-B^{*}$, and $L D H-C^{*}$ of Mugil sp. may be included in the bidirectionally divergent category. This category reflects the predominance of different genes in different tissues and was probably developed through alterations in the regulatory genes. According to the genetic evolution model proposed by Markert et al. (1975), loci which are expressed according to the bidirectionally divergent pattern would have reached a more advanced evolutionary stage, stimulated by continuous changes in their structure, function, and regulation. Our data are in accordance with those expected for the expression of both $L D H-A^{*}$ and $L D H-B^{*}$, since Perciformes consist of specialized fish. However, the less restricted expression of $L D H-C^{*}$ detected here disagreed with that expected for advanced fishes.

There are various studies of the influence of temperature on the activity of different fish enzymes and its repercussion on the physiology of these organisms (Hochachka and Lewis, 1970; Coppes et al., 1982; Schwantes and Schwantes, 1982a,b). Our thermostability results did not 
show the divergence found for paralogous forms of $\mathrm{LDH}$ (Plageman et al., 1960). Although slightly more thermostable than muscle extracts, those of heart did not show the typical response to temperature expressed in other species. Our data also showed that the thermal inactivation responses of muscle and heart extracts were independent of the SNS class of the individuals analyzed. Coppes et al. (1987), working with other Perciform species (Cynoscion striatus and Micropogonias opercularis), were not able to detect the LDH half-life of heart extracts with 60-min incubation at high temperatures, which characterizes the predominant B-isoform of this tissue as thermostable. However, working with $\mathrm{A}$ and $\mathrm{B}$-isoforms isolated by electrophoresis, and A-isoforms by chromatography, the values obtained here were quite close to those in the literature. While the enzymatic half-life of the A-homotetramer, predominant in muscle extracts, was 4-6 min, that of the B, predominant in heart, was $47 \mathrm{~min}$. The discrepancy observed between heart extract data and those of the B-homotetramers may be due to impurity of the heart extracts or the removal of enzymatic inhibitors and/or regulators, in the B-homotetramers.

According to Holbrook et al. (1975), A-isoforms are relatively insensitive to inhibition by the substrate, and are known as pyruvate reductases, which would have the function of maintaining redox equilibrium during anaerobiosis. On the other hand, B-isoforms are characteristically more susceptible to substrate inhibition, channeling more pyruvate into the Kreb's cycle and functioning mainly as lactate oxidases. The apparent $K_{\mathrm{m}}$ (pyr) values obtained here have been compared with other fish LDH $K_{\mathrm{m}}$ values (Wuntch and Goldberg, 1970; Panepucci et al., 1987; Coppes and Somero, 1990; Almeida-Val et al., 1991). All were found to be similar to $K_{\mathrm{m}}$ values obtained for muscle and heart LDH or their purified isoforms. Similar to those of the majority of vertebrates, kinetic properties of predominant isoforms in the different Mugil sp. tissues appeared to be different. As in other vertebrates, $\mathrm{LDH}$ affinity from heart extracts was shown to be 3.5 (SNS = 35)- to 4.4 (SNS = 39)-fold higher than that of skeletal muscle, i.e., the product of $L D H-A *$ has a lower affinity for the substrate than the product of $L D H-B^{*}$. This lower affinity allows it to play a metabolic role which has already been postulated for orthologous isoforms of other vertebrates (Hochachka and Somero, 1973).

Dissociation-association of LDH in solution was found to be influenced by the presence of coenzymes, substrates, or substrate analogues as well as by salts, temperature, and enzyme protein concentration (Yamamoto, 1983). The active dimer may be best suited for catalyzing the pyruvate reduction reaction whereas lactate oxidation may be most suitable function of the active tetramer (Yamamoto and Storey, 1988). Trausch and Schoffeniels (1969), verifying the effect of salt $(\mathrm{NaCl}$ and $\mathrm{KCl})$ concentration on the LDH isoforms of rabbit muscle, showed that the Bisoform, even in high salt concentrations, is unaffected. Bollette-Dugaillay and Schoffeniels (1969), working with stenohaline and euryhaline crustacean species, showed that independent of the pyruvate concentration in the assay, euryhaline $\mathrm{LDH}$ is inhibited by $\mathrm{NaCl}$. However, one of these stenohaline species, Maja squinado, was also inhibited by $\mathrm{NaCl}$, which could suggest that it is an euryhaline species, although never detected in estuarine areas. Since mullets inhabit unstable environments similar to that of estuaria, we could expect a high tolerance to changes in salinity. Similar to those described by Yamamoto (1983), our results on the $\mathrm{NaCl}$ effect on $K_{\mathrm{m}}$ and $V_{\text {max }}$ values of Mugil sp., 35 and 39 SNS individuals, indicate that this salt behaves as a competitive inhibitor, since it decreases their enzymesubstrate affinity. Lacerda (1996), working on MDH of individuals from this same lagoon-estuarine region, reported a reduction in the muscle enzyme-substrate affinity with $\mathrm{NaCl}$ addition but no effect in their heart extracts.

Ranzani-Paiva (1993), analyzing hematological data from 31-35 and 36-41 SNS individuals, suggested the occurrence of a single species in this region: Mugil platanus. In the same way, the data on electrokinetic (significantly different in comparisons between specimens with SNS of 33 and 39, but also between specimens with 38 and 39), thermostability behavior, $K_{\mathrm{m}}$ and $V_{\max }$ values and $\mathrm{NaCl}$ effect on these values (statistically different only for heart $V_{\max }$ values), obtained by us and Lacerda (1996), do not permit us to consider these mullet, with SNS ranging from 33 to 39 , as belonging to different populations or species.

\section{ACKNOWLEDGMENTS}

The authors wish to thank Dr. Alberto Carvalho Peret and José Roberto Verani for statistical analyses, and Dr. Paula Ann Matvienko-Sikar, who critically reviewed this manuscript. This work was supported by Conselho Nacional de Desenvolvimento Científico e Tecnológico (CNPq), and by Coordenadoria de Aperfeiçoamento de Pessoal de Ensino Superior (CAPES). Publication supported by FAPESP.

\section{RESUMO}

O número de escamas em séries laterais (SNS) de exemplares de Mugil sp. (Mugilidae, Perciformes) coletados na região estuarino-lagunar de Cananéia, Estado de São Paulo, varia de 33 a 39. A fim de tentar determinar se exemplares com diferentes SNS corresponderiam a diferentes espécies ou populações de tainhas, foram analisadas as propriedades eletrocinéticas, cinéticas e de termoestabilidade da sua lactato desidrogenase (LDH). A exemplo de muitos teleósteos, a LDH de Mugil sp. mostrou-se codificada por 3 locos gênicos: $L D H-A^{*}, L D H-B^{*}$ e $L D H-C^{*}$. Método de diluições seriadas aplicado a 10 diferentes tecidos dessa espécie sugeriu um padrão bidirecionalmente divergente de expressão desses locos da LDH. Não foi observada nenhuma associação entre padrão eletroforético, inativação térmica, respostas cinéticas e diferentes SNS. Os valores de $K_{\mathrm{m}}$ (pyr) aparente aqui obtidos mostraram-se similares aos obtidos por outros autores para músculo e coração, bem como aos de suas isoformas purificadas. O efeito do $\mathrm{NaCl}$ nos valores de $K_{\mathrm{m}} \mathrm{e} V_{\max }$ de Mugil sp. (SNS de 35 e 39) indica que esse sal se comporta como um inibidor competitivo, já que decresce a afinidade enzima- 
substrato. Assim, os comportamentos eletrocinéticos e de termoestabilidade, valores de $K_{\mathrm{m}}$ e $V_{\max }$ e os efeitos do $\mathrm{NaCl}$ sobre esses não nos permitem caracterizar as tainhas capturadas na região estuarino-lagunar de Cananéia, com amplitudes de SNS de 33 a 39, como diferentes espécies ou populações.

\section{REFERENCES}

Almeida-Val, V.M.F., Schwantes, M.L.B. and Val, A.L. (1990). LDH isozymes in Amazon fish. I. Electrophoretic studies on two species from Serrasalmidae family (Mylossoma duriventris and Colossoma macropomum). Comp. Biochem. Physiol. 95B: 77-84.

Almeida-Val, V.M.F., Schwantes, M.L.B. and Val, A.L. (1991). LDH isozymes in Amazon fish. II. Temperature and $\mathrm{pH}$ effects on LDH kinetic properties from Mylossoma duriventris and Colossoma macropomum (Serrasalmidae). Comp. Biochem. Physiol. 98B: 79-86.

Apella, E. and Markert, C.L. (1961). Dissociation of lactate dehydrogenase into subunits with guanidine hydrochloride. Biochem. Byophys. Res. Commun. 6: 171-176.

Bollette-Dugaillay, S. and Schoffeniels, E. (1969). Action des ions inorganiques sur l'activité de la deshydrogenase lactique de certains crustaces. Arch. Int. Physiol. Biochem. 77: 493-500

Boyer, S.H., Fainer, D.C. and Wason-Williams, E.S. (1963). Lactate dehydrogenase variant from human blood: evidence for molecular subunits. Science 141: 642-643.

Braga, F.F. (1978). Estudo morfológico comparativo das espécies do gênero Mugil linnaeus, da costa brasileira $\left(3^{\circ}-33^{\circ} \mathrm{S}\right)$. Master's thesis, Instituto Oceanográfico, USP, São Paulo, SP.

Coppes, Z. and Somero, G.N. (1990). Temperature-adaptive differences between the $\mathrm{M}_{4}$ lactate dehydrogenase of stenothermal and eurythermal Sciaenid fishes. J. Exp. Zool. 254: 127-131.

Coppes, Z., Schwantes, M.L.B. and Schwantes, A.R. (1982). Adaptive features of ectotermic enzymes. II. Studies on phosphoglucose isomerase (PGI) from five species of tropical fishes of the superorder Ostariophysi. Comp. Biochem. Physiol. 72B: 201-214.

Coppes, Z., Schwantes, M.L.B. and Schwantes, A.R. (1987). Adaptive features of enzymes from family Sciaenidae. III. Studies on lactate dehydrogenase (LDH) of fishes from the south coast of Uruguay. Comp. Biochem. Physiol. 88B: 1005-1012.

De Luca, P.H., Schwantes, M.L.B. and Schwantes, A.R. (1983). Adaptive features of ectothermic enzymes - IV. Studies on malate dehydrogenase of Astyanax fasciatus (Characidae) from Lobo reservoir (São Carlos, São Paulo, Brasil). Comp. Biochem. Physiol. 74B: 315-324.

Fenerich-Verani, N., Schwantes, M.L.B. and Schwantes, A.R. (1990). Patterns of gene expression during Prochilodus scrofa (Characiformes: Prochilodontidae) embryogenesis - I. Lactate dehydrogenase. Comp. Biochem. Physiol. 97B: 235-246.

Ferreira, N.C.A., Almeida-Val, V.M.F. and Schwantes, M.L.B. (1991). Lactate dehydrogenase (LDH) in 27 species of Amazon fish: adaptive and evolutive aspects. Comp. Biochem. Physiol. 100B: 391-398.

Ferris, S.E. and Whitt, G.S. (1979). Evolution of the differential regulation of duplicate genes after polyploidization. J. Mol. Evol. 12: 267-317.

Fisher, S.E. and Whitt, G.S. (1978). Evolution of isozyme loci and their differential tissue expression: creatine kinase as a model system. $J$. Mol. Evol. 12: 25-55

Goldberg, E. and Wuntch, T. (1967). The ontogeny of sperm specific lactate dehydrogenase in mice. J. Exp. Zool. 164: 309-316.

Hochachka, P.W. and Lewis, J.K. (1970). Enzyme variants in thermal acclimation: trout liver synthases. J. Biol. Chem. 245: 6567-6573.

Hochachka, P.W. and Somero, G.N. (1973). Strategies of Biochemical Adaptation. WB Saunders, Philadelphia.

Holbrook, P.W., Liljas, A., Steindal, S.J. and Rossman, M.G. (1975). Lactate dehydrogenase. In: The Enzymes (Boyer, P.D., ed.). Academic Press, New York, pp. 191-292.

Klebe, R.J. (1975). A simple method for the quantitation of isozyme patterns. Biochem. Genet. 11/12: 805-812.

Lacerda, F.S. (1996). Estudo da malato desidrogenase (MDH) em Mugil sp. (Osteichthyes, Mugilidae) de Cananéia (Estado de São Paulo). Master's thesis, Universidade Federal de São Carlos, São Carlos, SP.

Li, S.S.L., Fitch, W.M., Pan, Y.C.E. and Sharief, F.S. (1983). Evolutionary relationships of vertebrate lactate dehydrogenase isozymes A4 (muscle), B4 (heart), and C4 (testis). J. Biol. Chem. 258: 7029-7032.

Markert, C.L. and Faulhaber, I. (1965). Lactate dehydrogenase isozyme patterns of fish. J. Exp. Zool. 159: 319-332.

Markert, C.L., Shaklee, J.B. and Whitt, G.S. (1975). Evolution of a gene. Science 189: 102-114.

Menezes, N.A. (1983). Guia prático para conhecimento e identificação de tainhas e paratis (Pisces, Mugilidae) do litoral brasileiro. Rev. Bras. Zool. 2: 1-12.

Menezes, N.A. and Figueredo, J.L. (1985). Manual de Peixes Marinhos do Sudeste do Brasil - V. Teleostei. Museu de Zoologia, USP, São Paulo.

Panepucci, L.L., Schwantes, M.L.B. and Schwantes, A.R. (1984). Loci that encode the lactate dehydrogenase in 23 species of fish belonging to the orders Cypriniformes, Siluriformes and Perciformes: adaptive features. Comp. Biochem. Physiol. 77B: 867-876.

Panepucci, L.L., Schwantes, M.L.B. and Schwantes, A.R. (1987). Biochemical and physiological properties of the lactate dehydrogenase allozymes of the Brazilian teleost, Leporinus friderici, Anostomidae, Cypriniformes. Comp. Biochem. Physiol. 87B: 199-206.

Plageman, P.G., Gregory, K.F. and Wroblewski, F. (1960). The electrophoretically distinct forms of mammalian lactic dehydrogenase. II. Properties and interrelationships of rabbit and human lactic dehydrogenase isoenzymes. J. Biol. Chem. 235: 2288-2293.

Ranzani-Paiva, M.J.T. (1993). Características hematológicas associadas à biologia e parasitismo em Mugil platanus Günther, 1880 (Osteichthyes, Mugilidae) da região estuarino-lagunar de Cananéia - SP (Lat. $25^{\circ} 00^{\prime} \mathrm{S}$ - Long. $47^{\circ} 55^{\prime}$ W). Ph.D. thesis, Universidade Federal de São Carlos, São Carlos, SP.

Schwantes, M.L.B. (1973). Lactate dehydrogenase isozyme patterns of thirteen species of snakes. J. Exp. Zool. 185: 311-315.

Schwantes, M.L.B. and Schwantes, A.R. (1982a). Adaptive features of ectothermic enzymes. I. Temperature effects in the malate dehydrogenase from a temperate fish Leiostomus xanthurus. Comp. Biochem. Physiol. 72B: 49-58

Schwantes, M.L.B. and Schwantes, A.R. (1982b). Adaptive features of ectothermic enzymes. II. The effects of aclimation temperature on the malate dehydrogenase of the spot, Leiostomus xanthurus. Comp. Biochem. Physiol. 72B: 59-64.

Schwantes, A.R., Schwantes, M.L.B. and Beçak, W. (1969). Electrophoretic patterns of G-6-PD, 6-PGD and LDH in polyploid amphibians (Ceratophrydidae). Rev. Bras. Pesqui. Méd. Biol. 2: 41-44.

Shaklee, J.B. and Whitt, G.S. (1977). Patterns of enzyme ontogeny in developing sunfish. Differentiation 9: 85-95.

Shaklee, J.B., Kepes, K. and Whitt, G.S. (1973). Specialized lactate dehydrogenase isozymes: the molecular and genetic basis for the unique eye and liver LDHs of teleost fish. J. Exp. Zool. 185: 217-240.

Shaklee, J.B., Allendorf, F.W., Morizot, D.C.F. and Whitt, G.S. (1989). Genetic nomenclature for protein-coding loci in fish: proposed guidelines. Trans. Am. Fish. Soc. 118: 218-227.

Trausch, G. and Schoffeniels, E. (1969). De la structure quaternaire de la deshydrogenase lactique $\left(\mathrm{M}_{4}\right)$. I. Effects du $\mathrm{pH}$, du pyruvate et des ions inorganiques. Arch. Int. Physiol. Biochim. 77: 485-492.

Val, A., Schwantes, A.R., Schwantes, M.L.B. and De Luca, P.H. (1980). Amido hidrolisado de milho como suporte eletroforético. Ciênc. Cult. 33: 992-996.

Whitt, G.S., Shaklee, J.B. and Markert, C.L. (1975). Evolution of the lactate dehydrogenase isozymes of fishes. In: Isozymes IV: Genetics and Evolution (Markert, C.L, ed.). Academic Press, New York, pp. $381-400$.

Wuntch, T. and Goldberg, E.A. (1970). A comparative physicochemical characterization of lactate dehydrogenase isozymes in Brook trout, Lake trout and their hybrid Splake trout. J. Exp. Zool. 174: 233-252.

Yamamoto, S. (1983). H4-isozyme of lactate dehydrogenase in the solution of sodium chloride - 3 . The enzymatic activity and the pyruvate inhibition. Int. J. Biochem. 15: 185-190.

Yamamoto, S. and Storey, K.B. (1988). Dissociation-association of lactate dehydrogenase isozymes: influences on the formation of tetramers versus dimers of M4-LDH and H4-LDH. Int. J. Biochem. 20: 1261-1265.

Zar, J.H. (1974). Biostatistical Analysis. Prentice-Hall, New Jersey. 